\title{
The Effect of Inorganic and Organic Pre-reducing Agents on Selenium Analysis in Tomato Sample using Microwave- Assisted Digestion Followed by FI-HGAAS
}

\section{NUNTICHA LIMCHOOWONG ${ }^{1}$, PORNPIMON TAN-UMPORN ${ }^{1}$, LAMPAEN LAIJUNGRED ${ }^{1}$, SUCHILA TECHAWONGSTEIN ${ }^{2}$ and SAKSIT CHANTHAI ${ }^{*}$ *}

'Department of Chemistry and Center of Excellence for Innovation in Chemistry, Faculty of Science, Khon Kaen University, Khon Kaen - 40002, Thailand.

2Department of Plant Science and Agricultural Resources, Faculty of Agriculture, Khon Kaen University, Khon Kaen - 40002, Thailand.

${ }^{*}$ Corresponding author E-mail: sakcha2@kku.ac.th

http://dx.doi.org/10.13005/ojc/310118

(Received: December 06, 2014; Accepted: January 10, 2015)

\section{ABSTRACT}

\begin{abstract}
Optimum pre-reducing agents used to convert $\mathrm{Se}(\mathrm{VI})$ to $\mathrm{Se}(\mathrm{IV})$ for speciation analysis of inorganic selenium in tomato were investigated by FI-HGAAS. It was found that optimal conditions of $\mathrm{Se}(\mathrm{IV})$ consisted of $2 \mathrm{M} \mathrm{HCl}$ as carrier and $0.3 \%(\mathrm{w} / \mathrm{v}) \mathrm{NaBH}_{4}$ in $0.2 \%(\mathrm{w} / \mathrm{v}) \mathrm{NaOH}$ as reducing agent. Concerning the completely pre-reduction of $\mathrm{Se}(\mathrm{VI})$, various reducing agents were studied including $\mathrm{KCl}, \mathrm{KBr}, \mathrm{KI}$, ascorbic acid and thiourea in association with dilute and concentrate $\mathrm{HCl}$ and effect of temperature. From results, two optimal pre-reducing agents:0.5\%(w/v) Kl/conc. $\mathrm{HCl}$ and $0.5 \%(\mathrm{w} / \mathrm{v})$ thiourea/conc. $\mathrm{HCl}$ and heating for $30 \mathrm{~min}$ were chosen, giving a linearity between 5 and $25 \mathrm{ng} / \mathrm{mL}$. LOD and LOQ were 0.5 and $2 \mathrm{ng} / \mathrm{L}$, respectively. Both of pre-reducing agents were then applied to tomato digest based on dry basis of its sample, which comparatively resulted in $5.10 \mathrm{mg} \mathrm{Se}(\mathrm{IV}) / \mathrm{kg}$ and $29.12 \mathrm{mg} \mathrm{Se}(\mathrm{VI}) / \mathrm{kg}$ using $0.5 \%(\mathrm{w} / \mathrm{v}) \mathrm{KI} / \mathrm{conc}$. $\mathrm{HCl}$, and $3.84 \mathrm{mg} \mathrm{Se}(\mathrm{IV}) /$ $\mathrm{kg}$ and $22.29 \mathrm{mg} \mathrm{Se}(\mathrm{VI}) / \mathrm{kg}$ using $0.5 \%(\mathrm{w} / \mathrm{v})$ thiourea/conc. $\mathrm{HCl}$.
\end{abstract}

Key words: Selenium; Speciation; Pre-reduction; Tomato; FI-HGAAS.

\section{INTRODUCTION}

Selenium is an important trace element in biological and environmental systems ${ }^{1}$. This element is an essential trace mineral in the body. It is important part of antioxidant enzymes that protects cells against the effect of free radicals that are produced during normal oxygen metabolism. Selenium is also essential for normal functioning of the immune system and thyroid gland. Nevertheless, the biochemistry of selenium has shown that it has dual roles and the excess intake 
of selenium may be harmful to human body ${ }^{2}$.For the levels of selenium in toxicology, it has long been known that great differences in toxic properties occur among the various species of an element, because they follow different metabolic pathways. In particular, selenium absorption, retention and distribution within the body, and the amounts, forms and routes of excretion vary with the chemical forms and amounts of the element ingested ${ }^{3}$. It can be found naturally in four valence states including selenide, $\mathrm{Se}(-\mathrm{II})$, elemental $\mathrm{Se}(0)$, selenite, $\mathrm{Se}(\mathrm{IV})$ and selenate, $\mathrm{Se}(\mathrm{VI})$. Although precise feeding comparisons of the relative toxicity or nutritional activities of the different selenium compounds have not yet been made, it has been reported that the inorganic forms of Se are more toxic than the organic ones $^{4}$. For humans and most other mammals, the toxicity of inorganic selenium increases in the order: selenite $<$ selenate $<$ selenide $^{5}$. Selenium is primarily present as inorganic forms of $\mathrm{Se}(\mathrm{IV})$ and $\mathrm{Se}(\mathrm{VI})$ in the majority of environmental matrices such as water and soil 6 . The level of selenium species is common in the range of $\mu \mathrm{g} / \mathrm{L}$. Thus, the study of the selenium species in tomato would provide a better understanding of the requirements of this element in the living system.

Most methods for the selenium determination have reported as total selenium ${ }^{7}$. However, relatively few analytical methods have been applied for the selective determination of the different selenium species present in various matrices. Chromatographic techniques coupled with different detector systems have been extensively used for the separation and determination of all selenium species. This approach minimizes interferences from the matrix. However, errors may arise from a lack of efficiency in the separation, e.g. due to incomplete retention on the column, decomposition of the species, incomplete recovery of the eluate or peak overlap ${ }^{8}$. There are few electrochemical methods that can be applied for selenium speciation in biological fluids and environmental samples ${ }^{7,9,10}$. However, the complete mineralization or conversion of $\mathrm{Se}(\mathrm{VI})$ to $\mathrm{Se}(\mathrm{IV})$ (the electroactive form) makes sample preparation more complex and increases the risk of sample contamination and of losses of selenium. Spectrofluorimetric methods have been also used for the determination of the different inorganic species of selenium ${ }^{7,9}$. Although very sensitive, an initial acid digestion step is required for this technique and the analytical figures of merit may be markedly influenced by extraction solvent, temperature and the hydrogen ion concentration. The detection of methyl selenide species is carried out after gas chromatographic (GC) separation on the basis of their different retention times with a wide variety of detection methods such as electrothermal atomic absorption spectrometry (ETAAS) ${ }^{11}$ and microwave-induced helium plasma detection $(\mathrm{MWPO})^{12}$. The most commonly applied technique for inorganic selenium species determination is based on hydride generation (HG) with atomic absorption spectrometric (AAS) detection ${ }^{9}$. In all of these techniques, $\mathrm{Se}(\mathrm{IV})$ is determined directly after derivatization process, whereas $\mathrm{Se}(\mathrm{VI})$ is determined by difference value after reduction, and the organic selenium content is also determined by difference after destroying organic compounds by oxidation. These techniques are highly sensitive and yield detection limits in the $\mathrm{ng} / \mathrm{L}$ and are not subject to major interferences or high background noise levels ${ }^{13}$. The severe and systematic imprecision reported for this technique are almost due to the use of improper sample decomposition. The tolerance limits for other hydride-forming elements in the determination of selenium could be improved by one or two orders of magnitude by using a flow injection (FI) instead of a batch system and optimizing the analytical conditions systematically ${ }^{14}$. According to the literature on total selenium determination in biological and environmental materials, the combination of $\mathrm{FI}$ techniques with HGAAS is an accepted method ${ }^{15-18}$. In previous study, only one paper has described the $\mathrm{FI}$ closed system with thermal heating at $140^{\circ} \mathrm{C}$ for the determination of $\mathrm{Se}(\mathrm{IV})$ and $\mathrm{Se}(\mathrm{VI})$ by HGAAS with on-line prereduction of $\mathrm{Se}(\mathrm{VI})$ to $\mathrm{Se}(\mathrm{IV})^{19}$. No losses of selenium occur and the method has been successfully applied to the speciation of both inorganic species.

Although, FI-HGAAS can be used to determine Se(IV) only from the mixture of Se(IV) and $\mathrm{Se}(\mathrm{VI})$ solution, the concentration of $\mathrm{Se}(\mathrm{VI})$ is calculated by the difference between total inorganic Se and Se(IV). In the present study,the prevention of the back-oxidation of $\mathrm{Se}(\mathrm{IV})$ to $\mathrm{Se}(\mathrm{VI})$ by using various pre-reducing agents is aimed. Only Se(IV) forms the hydride, and so Se(VI) must be pre- 
reduced to $\mathrm{Se}(\mathrm{IV})$ if total selenium is to be determined. When $\mathrm{NaBH}_{4}$ is used as a reducing media for the determination of selenium by HGAAS, only $\mathrm{SeH}_{2}$, the $\mathrm{Se}(\mathrm{IV})$ redox state is determined directly. Total inorganic Se is determined after quantitative reduction of selenate to selenite. Considering that FI-HGAAS cannot detect $\mathrm{Se}(\mathrm{VI})$ directly, $\mathrm{Se}(\mathrm{VI})$ has to be reduced to $\mathrm{Se}(\mathrm{IV})$ first. Thus, the pre-reducing step to convert $\mathrm{Se}(\mathrm{VI})$ to $\mathrm{Se}(\mathrm{IV})$ is still necessary.

In this study, the optimal pre-reducing agents to convert $\mathrm{Se}(\mathrm{VI})$ to $\mathrm{Se}(\mathrm{IV})$ for ultra-trace analysis of an inorganic Se species and total Se are investigated using microwave-assisted digestion (MAD) and determination by FI-HGAAS. Application of the optimal pre-reducing agent of the Se species is then carried out with five varieties of tomato samples.

\section{MATERIALSAND METHODS}

\section{Chemicals and reagents}

All aqueous solution were prepared with deionized water (Milli Q Millipore 18.2 Mohm $\mathrm{cm}$ of resistivity) by Simplicity water purification system, Model Simplicity 185, Millipore Corporation (USA). All glasswares were cleaned by soaking in dilute $1 \%(\mathrm{v} / \mathrm{v}) \mathrm{HNO}_{3}$ overnight and rinsed two times with deionized water prior to use. A $1,000 \mathrm{mg} / \mathrm{mL} \mathrm{Se}(\mathrm{IV})$ stock solution was prepared from $\mathrm{SeO}_{2}$ (Carlo Erba, France) in $\mathrm{HCl}$ (Carlo Erba, France). A $1,000 \mathrm{mg} / \mathrm{mL}$ $\mathrm{Se}(\mathrm{VI})$ stock solution was prepared from $\mathrm{Na}_{2} \mathrm{SeO}_{4}$ (Sigma Aldrich, USA) stored in a refrigerator at $4^{\circ} \mathrm{C}$. Lower concentrations were prepared on the day by diluting the stock solution with $0.1 \mathrm{~mol} / \mathrm{L} \mathrm{HCl}$. The $0.3 \%(\mathrm{w} / \mathrm{v})$ of $\mathrm{NaBH}_{4}$ was prepared daily by dissolving $0.75 \mathrm{~g}$ of $\mathrm{NaBH}_{4}$ (Lab Chem, France) in $0.2 \%(\mathrm{~m} / \mathrm{v})$ $\mathrm{NaOH}$ (Carlo Erba, France) and diluting quantitatively to $250 \mathrm{~mL}$ with same solution. The carrier solution was $2.00 \mathrm{~mol} / \mathrm{L} \mathrm{HCl}$.

The pre-reducing agents included only conc. $\mathrm{HCl}$ or the solution containing $\mathrm{KBr}$ (Asia Pacific specialty, Australia) or thiourea (BDH laboratory supplies, England) in the presence of either conc. $\mathrm{HCl}$ or dilute $\mathrm{HCl}$ were employed to reduce $\mathrm{Se}(\mathrm{VI})$ to $\mathrm{Se}(\mathrm{IV})$. For digestion of tomato sample, 65\% (w/v) $\mathrm{HNO}_{3}$ (Lab Scan Asia, Thailand) was used.

\section{Instruments}

Selenium measurements were made using an atomic absorption spectrometer of the Perkin-Elmer AAnalyst 100 (Connecticut, USA) equipped with a flow injection analysis system Model FIAS-100 (Perkin Elmer Instruments, USA), used for continuous flow hydride generation. The FIAS-100 flow injection system consists of one peristaltic pump, five-port valve and a regulated gas control. Argon gas was used as carrier gas for the transposition of selenide $\left(\mathrm{SeH}_{2}\right)$ from the gasliquid separator to quartz tube atomizer. The selenium hollow cathode lamp (Victoria, Australia) was set at $196.0 \mathrm{~nm}$ wavelength, $16 \mathrm{~mA}$ lamp current and $2.00 \mathrm{~nm}$ slit width. A flow injection hydride generation system with a heated quartz tube atomizer was used for hydride generation and coupled to the AAS. PTFE tubing was used to transfer sample and solutions. The atomic absorption signal was measured as a peak height mode providing an analytical curve. The peristaltic pump, injection time and data acquisition were controlled through Perkin Elmer AA Winlab atomic absorption software version 3.2. The analytical conditions for FI-HGAAS determination are shown in Table 1.

Table 1: The operational conditions for the determination of Se by FI-HGAAS

\section{Parameter}

Spectrometer

Wavelength

$196.0 \mathrm{~nm}$

Slit width

$2.0 \mathrm{~nm}$

Measurement mode

Absorbance

Energy

25

Current of hollow cathode lamp $16 \mathrm{~mA}$

Hydride generation

Carrier

Reductant

$2.0 \mathrm{~mol} / \mathrm{L} \mathrm{HCl}$

$0.3 \%(\mathrm{w} / \mathrm{v})$

$\mathrm{NaBH}_{4}$ in $0.2 \%$

(w/v) $\mathrm{NaOH}$

Quartz cell temperature $\quad 900^{\circ} \mathrm{C}$

Sample loop volume $\quad 500 \mu \mathrm{L}$

Fill time $10 \mathrm{~s}$

Inject time $15 \mathrm{~s}$

Argon gas flow rate $\quad 50-55 \mathrm{~mL} / \mathrm{min}$ 
Materials

Tomato sample was soaked and washed with tap water followed by deionized water. The Seeda tomato as a model sample was homogenized. The homogenized fresh matter was transferred into PTFE centrifuge tube and freeze-dried (SCANVAC centrifuge for vacuum concentrator freeze-dry) at $20^{\circ} \mathrm{C}$. Once the samples were powdered and dried. They were kept at $-20^{\circ} \mathrm{C}$ prior to digestion. Approximately $0.2-0.5 \mathrm{~g}$ of the sample were weighed accurately, added $7 \mathrm{~mL} 65 \%(\mathrm{w} / \mathrm{v}) \mathrm{HNO}_{3}$ and $2 \mathrm{~mL}$ $37 \%(\mathrm{w} / \mathrm{v}) \mathrm{HCl}$. The sample mixture was digested under high temperature and pressure conditions using a microwave(Anton Parr 3000, Austria)unit at $220^{\circ} \mathrm{C}, 32.9 \mathrm{psi}, 800 \mathrm{~W}$ for $45 \mathrm{~min}$. After cooling, each solution was made up to $25 \mathrm{~mL}$ final volume with $0.1 \mathrm{~mol} / \mathrm{L} \mathrm{HCl}$. The digested clear sample solutions were further treated for the pre-reduction step of $\mathrm{Se}(\mathrm{VI})$ to $\mathrm{Se}(\mathrm{IV})$ prior to measurement by $\mathrm{FI}$ HGAAS as described below.

\section{Pre-reduction of $\mathrm{Se}(\mathrm{VI})$ to $\mathrm{Se}(\mathrm{IV})$}

Concerning the pre-reduction of $\mathrm{Se}(\mathrm{VI})$, various reducing agents were commonly used including some potassium halide salts $(\mathrm{KCl}, \mathrm{KBr}$ and $\mathrm{KI}$ ) and some organic compounds such as ascorbic acid and thiourea. The concentration of the pre-reduction agent was investigated in the ranges of $0.5,1.0,2.0,4.0,6.0,8.0,10.0$ and $12.0 \%$ $(\mathrm{w} / \mathrm{v})$. The experimental parameters mainly affecting on the pre-reduction step were as follows.

\section{Effect of pre-reducing agent}

To a standard solution of $20 \mu \mathrm{g} / \mathrm{LSe}(\mathrm{VI}), 1$ $\mathrm{mL}$ each of the pre-reducing agent was added, diluted to $10 \mathrm{~mL}$ with water and analyzed by FIHGAAS.

\section{Effect of pre-reducing agent in association with} dilute $\mathrm{HCl}$ or conc. $\mathrm{HCl}$

(i) Effect of the pre-reducing agent in association with dilute $\mathrm{HCl}$ : To standard solution of $20 \mu \mathrm{g} / \mathrm{L} \mathrm{Se}(\mathrm{VI})$, the pre-reducing agent and $2 \mathrm{~mL}$ of $6 \mathrm{~mol} / \mathrm{L} \mathrm{HCl}$ were added, diluted to $10 \mathrm{~mL}$ with deionized water and analyzed by FI-HGAAS.

(ii) Effect of the pre-reducing agent in association with concentrate $\mathrm{HCl}$ : To standard solution of $20 \mu \mathrm{g} / \mathrm{L} \mathrm{Se}(\mathrm{VI})$, the prereducing agent and $2 \mathrm{~mL}$ of conc. $\mathrm{HCl}$ were added, diluted to $10 \mathrm{~mL}$ with deionized water and analyzed by FI-HGAAS.

\section{Effect of temperature}

(i) Effect of the pre-reducing agent and heating: To standard solution of $20 \mu \mathrm{g} / \mathrm{L} \mathrm{Se}(\mathrm{VI})$, the pre-reducing agent was added $1 \mathrm{~mL}$, heated in a water bath at $70-80^{\circ} \mathrm{C}$ for $30 \mathrm{~min}$, cooled down, diluted to $10 \mathrm{~mL}$ with deionized water, and analyzed by FI-HGAAS.

(ii) Effect of the pre-reducing agent in association with dilute $\mathrm{HCl}$ and heating: To standard solution of $20 \mu \mathrm{g} / \mathrm{L} \mathrm{Se}(\mathrm{VI})$, the prereducing agent $1 \mathrm{~mL}$ and $2 \mathrm{~mL}$ of $6 \mathrm{~mol} / \mathrm{L}$ $\mathrm{HCl}$ were added, heated in a water bath at $70-80^{\circ} \mathrm{C}$ for $30 \mathrm{~min}$, cooled down, diluted to $10 \mathrm{~mL}$ with deionized water, and analyzed by FI-HGAAS.

(iii) Effect of the pre-reducing agent in association with conc. $\mathrm{HCl}$ and heating: To standard solution of $20 \mu \mathrm{g} / \mathrm{L} \mathrm{Se}(\mathrm{VI})$, the prereducing agent $1 \mathrm{~mL}$ and $2 \mathrm{~mL}$ of conc. $\mathrm{HCl}$ were added, heated in a water bath at 70$80^{\circ} \mathrm{C}$ for $30 \mathrm{~min}$, cooled down, diluted to 10 $\mathrm{mL}$ with deionized water, and analyzed by FI-HGAAS.

\section{RESULTS AND DISCUSSION}

\section{The optimal pre-reduction agents}

Without $\mathrm{HCl}$, no signal was detected by $\mathrm{FI}$ HGAAS. From the results, five optimal pre-reducing agents were chosen for further studies (Fig. 1) consisting of $0.5 \%(\mathrm{w} / \mathrm{v}) \mathrm{KI} /$ conc. $\mathrm{HCl} /$ heat, $0.5 \%$ (w/ v) Thiourea/cocn. $\mathrm{HCl} /$ heat, $1.4 \%(\mathrm{w} / \mathrm{v}) \mathrm{KBr} /$ dilute $\mathrm{HCl} /$ heat, $0.8 \%$ (w/v) $\mathrm{KBr} /$ conc. $\mathrm{HCl} /$ heat, and $1.3 \%$ (w/v) $\mathrm{KCl} /$ conc. $\mathrm{HCl} /$ heat.

In the cases of $1.4 \%(\mathrm{w} / \mathrm{v}) \mathrm{KBr} /$ dilute $\mathrm{HCl}$, $0.8 \%(\mathrm{w} / \mathrm{v}) \mathrm{KBr} /$ conc. $\mathrm{HCl}$ and $1.3 \%(\mathrm{w} / \mathrm{v}) \mathrm{KCl} /$ conc. $\mathrm{HCl}$ followed by heating for $30 \mathrm{~min}$, the pre-reducing agents should not be suitable for reducing $\mathrm{Se}(\mathrm{VI})$ to be $\mathrm{Se}(\mathrm{IV})$ because they were affected due to strong sample matrix.Only two optimum pre-reducing agents: $0.5 \%(\mathrm{w} / \mathrm{v}) \mathrm{KI} /$ conc. $\mathrm{HCl}$ and $0.5 \%(\mathrm{w} / \mathrm{v})$ thiourea/conc. $\mathrm{HCl}$ and heating for $30 \mathrm{~min}$ were chosen for the standard solution of $\mathrm{Se}(\mathrm{VI})$. Application of these pre-reducing agents was then carried out with real sample of tomato prepared by microwave-assisted digestion. Consequently, both 
of them can be used as the calibration curve for the determination of inorganic Se species and total Se in tomato sample as shown in Table 2.

Table 2: The pre-reducing agents used and selenium contents $(\mathrm{mg} / \mathrm{Kg})$ found in tomato sample

\begin{tabular}{lccc} 
Pre-reducing agent & Se $_{\text {total }}$ & $\operatorname{Se}(\mathrm{IV})$ & $\mathrm{Se}(\mathrm{VI})$ \\
\hline $0.5 \%(\mathrm{w} / \mathrm{v}) \mathrm{KI} / \mathrm{conc} . \mathrm{HCl}$ & 34.22 & 5.10 & 29.12 \\
$\begin{array}{l}0.5 \%(\mathrm{w} / \mathrm{v}) \text { Thiourea/ } \\
\text { conc. } \mathrm{HCl}\end{array}$ & 26.13 & 3.84 & 22.29 \\
\hline
\end{tabular}

\section{Analytical figures of merit}

The calibration curve was constructed between $0.5 \mu \mathrm{g} / \mathrm{L}$ and $50.0 \mu \mathrm{g} / \mathrm{L}$ and the linearity was maintained up to $100.0 \mu \mathrm{g} / \mathrm{L}$ with a correlation coefficient $\left(r^{2}\right)$ greater than 0.999 . Limits of detection (LOD) and quantification (LOQ) calculated as three and ten times standard deviation of absorbance signal of 10 reagent blanks divided by the standard calibration slope of Se(IV) were found to be $0.5 \mu \mathrm{g} /$ $\mathrm{L}$ and $2 \mu \mathrm{g} / \mathrm{L}$, respectively. This LOD was less than those previously reported ${ }^{20-21}$. The precision was less than $10 \% \operatorname{RSD}(n=3)$. The precisions of the calibration curve of $\mathrm{Se}(\mathrm{IV})$ standard solution between $5 \mu \mathrm{g} / \mathrm{L}$ and $25 \mu \mathrm{g} / \mathrm{L}(n=10)$ were shown within the acceptable ranges as RSD of $9.4 \%$ and $10.3 \%$ for an inter-day and an intra-day analysis. The results gave rather higher precision for each of the calibration curve for Se speciation analysis.

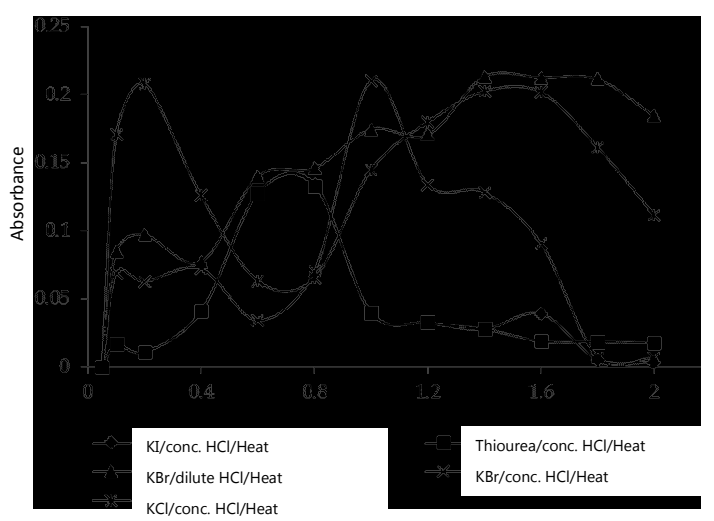

Fig. 1: The effect of various pre-reducing agents for $\mathrm{Se}(\mathrm{VI})$ solution on the absorbance of $\mathrm{Se}$ (IV) under hydride generation
The speciation study of $\mathrm{Se}(\mathrm{IV}), \mathrm{Se}(\mathrm{VI})$ and both Se species using the selected four prereduction systems were demonstrated that all the reducing systems gave rather high content for these Se species (3.84-5.10, 22.29-29-12 and 26.13$34.22 \mathrm{mg} / \mathrm{Kg}$ for Se(IV), Se(VI) and total Se, respectively) spiked in the Seeda tomato sample. For sample digestion, the main problem may arise from the peculiar chemical resistance of some organoselenium compounds (selenoamino acid, selenonium salts) to be transformed into inorganic Se salts, selenite or selenate forms. Tomatoes have rather high organic selenium ${ }^{17}$. The residues of organic matter, however, could interfere the hydride generation, if the acid digestion of the sample was not completed. Concerning on the inorganic Se species in the tomato samples, the hexavalent Se is found in higher contents than the tetravalent one.

\section{CONCLUSION}

To find out the optimized conditions for Se speciation by FI-HGAAS, using of $2 \mathrm{~mol} / \mathrm{L} \mathrm{HCl}$ solution as carrier associated with a solution of $0.3 \%$ (w/v) $\mathrm{NaBH}_{4}$ in $0.2 \%$ (w/v) $\mathrm{NaOH}$ was run. However, the difference in the absorbance signals obtained from tratavalent and hexavalent selenium depends very strongly on the pre-reduction system used under the experimental conditions. Since Se(VI) gives very low signal in HGAAS system, the off-line pre-reduction of $\mathrm{Se}(\mathrm{VI})$ to $\mathrm{Se}(\mathrm{IV})$ must be completed. For this reason, the pre-reduction procedure for the digested samples was also optimized once in details. The sample digestion was conducted with a microwave unit under high temperature and pressure. It is fast and safe compared with common acid digestion in hood. Consequently, the proposed method was applied for analysis of inorganic Se in tomato. The pre-reduction step made possibly the completeness of the inorganic Se species determination. The use of a mixture of the prereducing agents permitted the quantitative reduction of $\mathrm{Se}(\mathrm{VI})$ to $\mathrm{Se}(\mathrm{IV})$ under mild experimental conditions.

\section{ACKNOWLEDGEMENTS}

This research was supported by the Higher Research Promotion and National Research University Project of Thailand, Office of the Higher 
Education Commission, through the Food and Functional Food Research Cluster of Khon Kaen University. The Center of Excellence for Innovation in Chemistry (PERCH-CIC) and Commission on Higher Education, Ministry of Education.

\section{REFERENCES}

1. Rayman, M.P.; Phil, D. Lancet.2000, 356, 233-241.

2. Sun, Y.C.; Chang, Y.C.; Su, C.K. Anal Chem.2006,78, 2640-2645.

3. Underwood, E.I., Selenium in Trace Elements in Human and Animal Nutrition. New York,(1977).

4. Narasaki, H.; Mayumi, K. Anal Sci.2000, 16, 65-68.

5. Petropoulou, M.O.;Michalke, B.;Kavouras, D.;Schramel, P.Anal Chim Acta.2003, 478, 219-227.

6. Campillo, N.;Aguinaga, N.;Viñas, P.;LópezGarcía, I.; Hernández-Córdoba, M.J. Chromatogr A.2005, 1095, 138-144.

7. Alaejos, M.; Romero, C.Chem Rev.1995, 95, 227-257.

8. Raptis, S.E.; Kaiser, G.;Tolg, G. Anal Chem.1983, 316, 105-123.

9. Mufioz, R.;Donard, O.;Camara, C.; Ouevauviller, P. Analy Chim Acta.1994, 286, 357-370.

10. Bryce, D.W.;Izquierdo, A.;Luque de Castro,
M.D. Anal Chim Acta.1995, 308, 96-101.

11. Jiang, S.;Robberecht, H.; Adams, F.; Van der Berghe, D. ToxicolEnviron Chem.1983, 6, 191-201.

12. Olsen, K.B.;Sklarew, D.S.; Evans, J.C.Spectrochim Acta.1985, 40, 357-365.

13. Verlinden, M.;Deelstra, H.A.;Adrianensses, E. Talanta,1981, 28, 637-646.

14. Welz, B.;Stauss, P.SpectrochimActa B.1993, 48, 951-976.

15. Chan, C.C.Anal Chem.1985, 57, 1482-1485.

16. Fang, Z.; Xu, S.; Wang, X.; Zhang, S.Anal ChimActa.1986, 179, 169-179.

17. Ikeda, M.Anal ChimActa.1985, 170, 217-224.

18. Pyen, G.S.; Browner, R.F. App/Spectro.1988, 42, 508-512.

19. Cobo, M.G.; Palacios, M.A. Anal ChimActa.1993, 283, 386-392.

20. Li, F.;Goessler, W.;Irgolic, K. Anal Com. 1998, 35, 361-364.

21. Sigrist, M.; Brusa, L. Campagnoli D, Beldoménico H.Food Chem.2012,134, 1932-1937. 